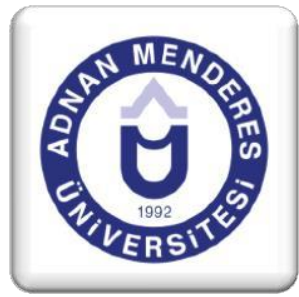

\section{A Turkish Translation Of The Emotion Words Prompt List: The EWPL-TR ${ }^{1}$}

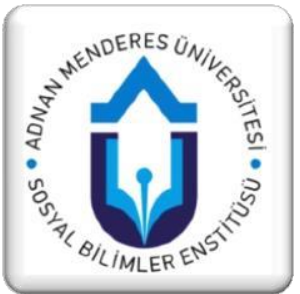

\begin{abstract}
It is highly critical to create and develop usable and effective systems so that studies on users' emotional behaviour as an vital angle of users' experience with systems have been getting expanding consideration in the last decade. The Emotion Word Prompt List (EWPL) scale that was developed in English has been used in the literature for assessing users' emotions with interactive systems. This study aimed to adapt the EWPL into Turkish and investigate its reliability and validity. To verify the translation, two professional translation techniques that are multiple forward and back-translation techniques were used and four translators were employed. The official Turkish version of the EWPL (EWPL-TR) conducted to 324 university students. The EWPL-TR's reliability was found at a high level. As a result of the item analysis, the number of questions was reduced to 15, in order to get better results. Besides, confirmatory factor analysis (CFA) successfully revealed the two-factor structure of the EWPL-TR. The results of this study showed that the EWPL-TR is a reliable and valid scale for understanding user emotions on systems.
\end{abstract}

Keywords: emotion words prompt list, Turkish, reliability, validity

\title{
Duygusal Kelime İstem Listesinin Türkçe 'ye Çevirisi
}

\section{ÖZET}

Kullanılabilir ve etkili sistemler oluşturmak ve geliştirmek o kadar önemlidir ki, kullanıcıların sistemlerle ilgili deneyimleri kapsamında duygusal davranışları hakkındaki çalışmalar son on yılda giderek artmaktadır. Literatürde kullanıcıların duygularını interaktif sistemlerle değerlendirmek için İngilizce olarak geliştirilen Duygusal Kelime İstem Listesi (EWPL) ölçeği kullanılmıştır. Bu çalışma EWPL ölçeğini Türkçe 'ye uyarlamayı ve güvenilirliğini ve geçerliliğini araştırmayı amaçlamıştır. Çeviriyi doğrulamak için, çoklu ileri ve geri çeviri teknikleri olan iki profesyonel çeviri tekniği kullanılmış ve dört çevirmen ile çalışılmıştır. EWPL ölçeğinin resmi Türkçe versiyonu (EWPL-TR) 324 üniversite öğrencisine uygulanmıştır. EWPL-TR'nin güvenilirliği yüksek düzeyde bulunmuştur. Maddelerin analizi sonucunda daha iyi sonuçlar elde etmek için soru sayısı 15'e düşürülmüştür. Ayrıca, doğrulayıcı faktör analizi (CFA), EWPL-TR'nin iki faktörlü yapısını başarıyla ortaya koymuştur. Bu çalışmanın sonuçları, EWPL-TR'nin kullanıcıların sistemler ile ilgili duygularını anlamak için güvenilir ve geçerli bir ölçek olduğunu göstermiştir.

Anahtar kelimeler: duygusal kelime istem listesi, Türkçe, geçerlilik, güvenilirlik

\footnotetext{
${ }^{1}$ This work was produced from the thesis entitled "Evaluation of a Student Information System (SIS) in terms of User Emotions, Performance and Perceived Usability: A Turkish University Case", which has been defended at the 07.06.2018 master thesis under Dr. Cagla Seneler academic consultancy.

${ }^{2}$ Research Assistant, Adnan Menderes University, Department of Management Information Systems, AYDIN, e-mail: denizhan.demirkol@adu.edu.tr

${ }^{3}$ Assistant Professor Doctor, Yeditepe University, Department of Management Information Systems, ISTANBUL, e-mail: cagla.seneler@yeditepe.edu.tr
} 
Adnan Menderes Üniversitesi, Sosyal Bilimler Enstitüsü Dergisi, Cilt: 5, Sayı: 2(Sf. 218-235)

Adnan Menderes University, Journal of Institute of Social Sciences, Vol.:5, No: 2 (pp. 218-235)

\section{Introduction}

User experience (UX) is a concept universally used in human-computer interaction (HCI), both in research and practice. User experience has three main typical features which are "user", "that user is interacting with a product, system, or really anything with an interface" and "the user's experience is of interest, and observable or measurable" (Tullis \& Albert, 2013). The studies about users' emotional behaviour as an vital angle of the users' experience with systems have been getting expanding consideration in the last decade. User emotion is an important issue in HCI (Palen \& Bødker, 2008) and it is extremely important to take the informative function of emotions into account when designing HCI interfaces (Kim \& Moon, 1998). According to Jordan (1998) creating usable products may not the same meaning as creating pleasurable products. Positive emotional experiences with an interactive product are assumed to lead to good user experience (Seneler, 2014) and, ultimately, to product success (Kujala \& Miron-Shatz, 2013).

Mahlke and Minge (2008) asserted that user emotions can be measured through various ways such as heart rate and electro dermal activity (EDA), electromyography (EMG) or pupil responses, the analysis of facial expressions captured by video, or various kinds of survey methods such as questionnaires, scales, interviews, etc. According to Mauss and Robinson (2009) there is no "gold standard" measure of emotional responding and self-reports of emotion are likely to be more valid to the extent that they relate to currently experienced emotions. Thus, questionnaires or scales can be used to measure the emotional reactions of users in a practical way. A variety of questionnaires and scales have been used and reported in the literature for assessing the perceived emotion (Harniss, Epstein, Ryser, \& Pearson, 1999; Garnefski \& Kraaij, 2007; Petrie \& Precious, 2010).

Previous research (Harrison, 2009; Petrie \& Harrison, 2009) showed that some people find the emotional think aloud difficult to do (perhaps more so than doing a traditional think aloud). Users often report that it is difficult to express their feelings about a website. In order to overcome this problem it has been explored the usefulness of providing users with an Emotion Word Prompt List (EWPL) that is a list of emotion words commonly used in describing websites (Petrie \& Harrison, 2009). EWPL was the one of two techniques that Petrie and Precious (2010) used in their studies to develop simple yet effective methods for obtaining user experience of websites and other interactive technologies. It was found that the use of EWPL helps users to express their emotional reactions to websites. According to Petrie and Harrison (2009) EWPL can be effectively used as a rating scale measure to be completed after interaction with a website, which is a very efficient method of measuring emotional reaction to a website. The EWPL scale has been conducted in the literature successfully (Seneler, 2014). Seneler (2014) found that positive emotions bring high usability rating of a website and negative emotions bring low usability rating for the website. Thus, focusing on users' emotional reactions has a potential to raise websites' usability ratings.

EWPL is quick, understandable and practical scale for assessing user emotion. In EWPL, participants' immediate emotional reactions to the website were measured using a 16 item scale of emotion words commonly used to describe reactions to web sites. Participants rated each emotion word in response to the question "To what extent did the website make you feel each of the following?" on a 5 point scale (from $1=$ Not at all to $5=$ Very). EWPL consists of 9 positive, 6 negative and 1 ambiguous word (See Table A.1 in Appendix for the EWPL). 
The EWPL scale was developed in English. There are studies that showed participants respond better to scales in their own language (Bahrick, Hall, Goggin, Bahrick \& Berger, 1994; Delgado, Guerrero, Goggin \& Ellis, 1999). However, the authors of this paper have failed to find a Turkish version of the EWPL (a fact confirmed by EWPL's main author, Professor Helen Petrie). Therefore, to make it suitable for users and researchers from Turkey, EWPL was translated into the Turkish language with permission of Professor Helen Petrie and its reliability and validity studies have been done.

\section{Methodology}

\subsection{Translation method of the EWPL into Turkish}

With permission from its main author, Professor Dr. Helen Petrie, the EWPL was translated into Turkish. In order to validate translations and to reduce the risks that can be faced while translating from one language to another, two different translation techniques were used. Although most studies that have translated questionnaires or scales into other languages have applied one of the each translation techniques during the translation process (Isemonger \& Sheppard, 2007), the use of both multiple forward and back-translation techniques in this study prevented poor translations and enabled translations to be crosschecked. In order to translate the EWPL into Turkish, four translators who are native speakers of Turkish and advanced speakers of English were employed. These four translators will be referred to as Translator1, Translator2, Translator3 and Translator4 in this text.

In the first phase, a multiple forward translation technique was used. A multiple forward translation technique is the translation of a document from the source language into the target language independently by a number of translators (Maxwell, 1996). Translator1 and Translator 2 undertook two independent translations. Then two people as a native speaker of Turkish and fluent English speaker compared these translations on an item-to-item basis in order to identify any differences in meaning. Then, Translator3 was asked to translate only the different parts of the first two translations. Next, the efforts of all three translators were evaluated and these efforts produced an overall first translation (See Figure 1). 


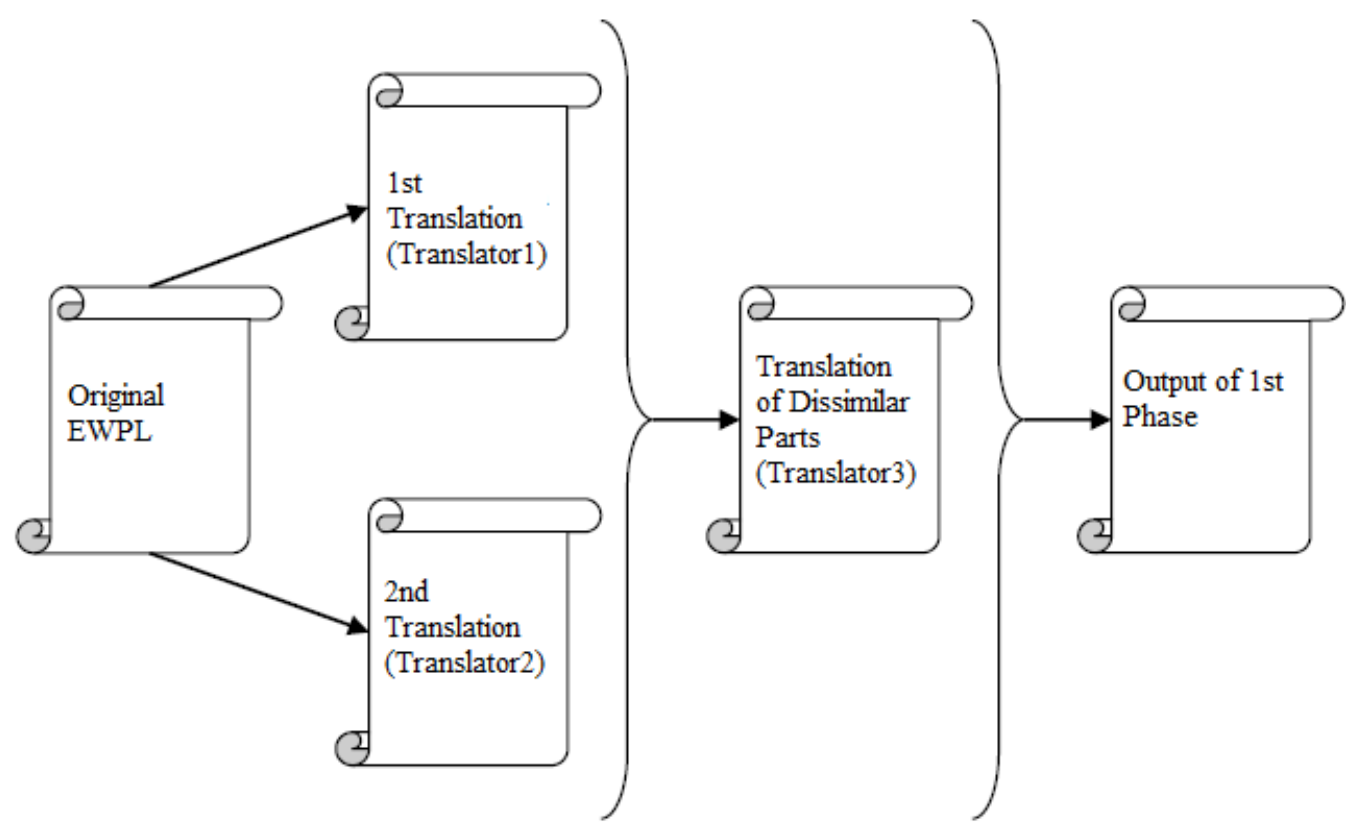

Figure 1: First Phase of the Translation Process

In the second phase, a back-translation technique was used, that is a translation of a document that has been already translated into a target language back into the source language (Maxwell, 1996). Translator4 was asked to translate the output of first phase (the overall first translation of the EWPL) back into English (See Figure 2).

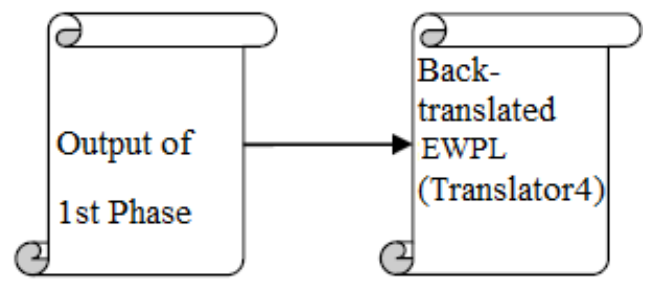

Figure 2: Second Phase of the Translation Process

Figure 3, below, shows the third phase of EWPL translation process. In the last phase of translation process, the original EWPL and the back-translated EWPL were compared. Appropriate modifications were made and the Turkish version of EWPL was finalized (See Table A.2 in Appendix for the EWPL-TR). 


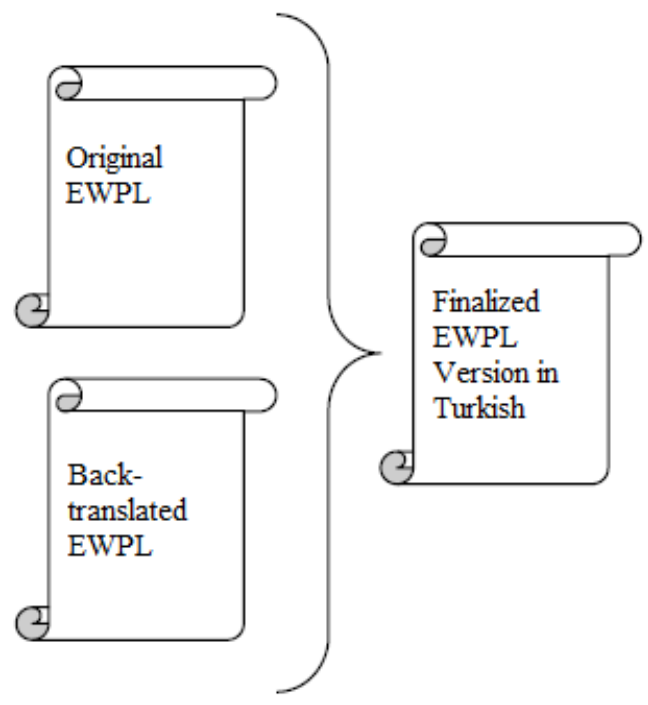

Figure 3: Third Phase of the Translation Process

\subsection{Reliability and validity study of the Turkish version of the EWPL (EWPL-TR)}

\subsubsection{Method}

After the translation process has ended, the scale was conducted to study reliability and validation of it. Before putting the scale into practice, a pilot study was conducted with six undergraduate students from a Turkish University to determine unrecognized and unclear points and to get any feedback. After that, the data were collected by a two-part questionnaire. In the first part of the questionnaire, participants were asked to give answers on the EWPL-TR scale. The questions in this section are of the Likert type of 5 ( 1 = "Strongly disagree" and $5=$ "Strongly agree"). In the second part of the questionnaire, demographic information such as age, gender, department and questions that determine the duration of web usage were included.

In the data collection process, an electronic version of the questionnaire was prepared so that it was applied online. The address of the electronic questionnaire is sent by e-mail to the students and it was also implemented online in several lectures. The data collection process lasted four weeks in total.

\subsubsection{Participants}

The scale was applied to 324 undergraduate students from a Turkish University. As it is illustrated in the following table (See Table 1), 50\% of the participants are female and $50 \%$ of the participants are male. Almost all participants' ages are between 18-25 years. 
Table 1: Gender and age information of the working group

\begin{tabular}{lccc}
\hline & & $\mathrm{f}$ & $\%$ \\
\hline \multirow{2}{*}{ Gender } & Female & 162 & 50 \\
& Male & 162 & 50 \\
\hline \multirow{6}{*}{ Age } & 18 & 5 & 1.5 \\
& 19 & 31 & 9.5 \\
& 20 & 61 & 18.8 \\
& 21 & 62 & 19.1 \\
& 22 & 76 & 23.4 \\
& 23 & 38 & 11.7 \\
& 24 & 23 & 7.0 \\
& 25 & 15 & 4.6 \\
& 26 & 5 & 1.5 \\
& 27 & 4 & 1.2 \\
Total & 28 & 3 & 0.9 \\
\hline
\end{tabular}

The average age of the participants is 20 . The participants mentioned that $92.9 \%$ of them use the web every day. A large majority of participants $(70.4 \%)$ use computers over 10 years. Almost half of the participants (55.2\%) stated that their confidence about computer use could change depending on the given task. Furthermore, $40.1 \%$ of the participants expressed that they are confident about using computers. Only one participant mentioned that $\mathrm{s} / \mathrm{he}$ does not feel confidence and trust about her/his computer usage at all (See Table 2).

Table 2: Web usage, computer usage and confidence statistics of the participants

\begin{tabular}{|c|c|c|c|}
\hline & Items & $\mathrm{f}$ & $\%$ \\
\hline \multirow{3}{*}{ Web usage } & Everyday & 301 & 92.9 \\
\hline & Several times a week & 22 & 6.8 \\
\hline & Several times a month & 1 & 0.3 \\
\hline Total & & 324 & 100 \\
\hline \multirow{4}{*}{ Computer usage } & $3-5$ years & 6 & 1.8 \\
\hline & $5-7$ years & 22 & 6.8 \\
\hline & $7-10$ years & 68 & 21 \\
\hline & 10 years and over & 228 & 70.4 \\
\hline Total & & 324 & 100 \\
\hline \multirow{4}{*}{ Computer usage confidence } & Do not trust & 1 & 0.3 \\
\hline & Usually need help & 14 & 4.3 \\
\hline & Depends on the given task & 179 & 55.2 \\
\hline & Trust & 130 & 40.2 \\
\hline Total & & 324 & 100 \\
\hline
\end{tabular}

\subsubsection{Item analysis}

Item analysis uses statistics and expert judgment to evaluate tests based on the quality of individual items, item sets, and entire sets of items, as well as the relationship of each item to other items. It explores the performance of items considered separately either in relation to some external criterion or in relation to the remaining items on the test (Thompson \& Levitov, 1985). The items should be extracted from scale if the relation of one item to the other items is below 0.30 (Büyüköztürk, Çakmak, Akgün, Karadeniz \& Demirel, 2017). Item-total statistics of the EWPL-TR are given in following table (See Table 3). 
Table 3: Item-total statistics of the EWPL-TR

\begin{tabular}{lcccl}
\hline ITEMS & $\begin{array}{c}\text { Scale Mean } \\
\text { if Item } \\
\text { Deleted }\end{array}$ & $\begin{array}{c}\text { Scale } \\
\text { Item } \\
\text { Deleted }\end{array}$ & $\begin{array}{c}\text { Corrected } \\
\text { Item-Total } \\
\text { Correlation }\end{array}$ & $\begin{array}{l}\text { Cronbach's } \\
\text { Alpha } \\
\text { if Item Deleted }\end{array}$ \\
\hline Item1 & 33.966 & 124.708 & 0.743 & 0.885 \\
\hline *Item2 & 33.969 & 123.776 & 0.639 & 0.888 \\
\hline *Item3 & 33.982 & 123.802 & 0.652 & 0.888 \\
\hline Item4 & 34.198 & 127.496 & 0.614 & 0.889 \\
\hline *Item5 & 33.679 & 129.302 & 0.437 & 0.896 \\
\hline Item6 & 34.756 & 131.405 & 0.515 & 0.893 \\
\hline Item7 & 34.466 & 130.113 & 0.465 & 0.894 \\
\hline *Item8 & 34.040 & 122.107 & 0.682 & 0.886 \\
\hline *Item9 & 34.179 & 123.559 & 0.604 & 0.889 \\
\hline Item10 & 34.355 & 125.388 & 0.771 & 0,885 \\
\hline Item11 & 34.244 & 126.216 & 0.674 & 0.887 \\
\hline Item12 & 34.225 & 125.890 & 0.633 & 0.888 \\
\hline Item13 & 34.346 & 125.081 & 0.762 & 0.885 \\
\hline Item14 & 34.386 & 126.362 & 0.668 & 0.888 \\
\hline Item15 & 33.991 & 146.003 & -0.124 & 0.916 \\
\hline Rotated & 33.608 & 124.666 & 0.520 & 0.893 \\
\hline & & & \\
\hline
\end{tabular}

Since the relation of one item to the other items should not be below 0.30 , each item that is lower than this value was subtracted from the scale (subtraction was started from the item that has the lowest value). When each item was subtracted from the scale, the item analysis was repeated. This process has been continued until the material has come to a level below 0.30. The final state of the scale is given in the following table (See Table 4). The table shows the results after the extraction of the item "Item 15 " from the scale. In the scale form, there are 16 questions related to EWPL. As a result of the item analysis, the number of questions was reduced to 15 . 
Table 4: Item - total statistics (after item extraction)

\begin{tabular}{lllll}
\hline ITEMS & $\begin{array}{l}\text { Scale } \\
\text { Mean if } \\
\text { Item } \\
\text { Deleted }\end{array}$ & $\begin{array}{l}\text { Scale } \\
\text { Variance } \\
\text { if Item } \\
\text { Deleted }\end{array}$ & $\begin{array}{l}\text { Corrected } \\
\text { Item-Total } \\
\text { Correlation }\end{array}$ & $\begin{array}{l}\text { Cronbach's } \\
\text { Alpha if Item } \\
\text { Deleted }\end{array}$ \\
\hline Item1 & 31.531 & 126.652 & 0.748 & 0.907 \\
\hline Item2 & 31.534 & 125.277 & 0.659 & 0.910 \\
\hline *Item3 & 31.546 & 125.357 & 0.672 & 0.909 \\
\hline Item4 & 31.762 & 129.761 & 0.607 & 0.912 \\
\hline *Item5 & 31.244 & 130.730 & 0.461 & 0.917 \\
\hline Item6 & 32.321 & 133.748 & 0.505 & 0.914 \\
\hline Item7 & 32.031 & 132.884 & 0.439 & 0.917 \\
\hline *Item8 & 31.605 & 123.577 & 0.703 & 0.908 \\
\hline *Item9 & 31.744 & 124.971 & 0.627 & 0.911 \\
\hline Item10 & 31.920 & 127.653 & 0.762 & 0.907 \\
\hline Item11 & 31.809 & 128.675 & 0.658 & 0.910 \\
\hline Item12 & 31.790 & 128.234 & 0.622 & 0.911 \\
\hline Item13 & 31.911 & 127.141 & 0.762 & 0.907 \\
\hline Item14 & 31.951 & 128.716 & 0.656 & 0.910 \\
\hline *Item16 & 31.173 & 125.778 & 0.552 & 0.914 \\
\hline *Rotated. & & & & \\
\hline & & & & \\
\hline
\end{tabular}

\subsubsection{Reliability analysis}

Reliability was assessed using coefficient alpha (Cronbach, 1951) and it is generally accepted method for measuring reliability (Sauro and Lewis, 2012). It was determined that the reliability level of the EWPL-TR consisting of 15 items was at a high level which is 0.9 (See Table 5).

Table 5: Reliability coefficients

\begin{tabular}{ccc}
\hline Cronbach's Alpha & N of Items & N of Cases \\
\hline 0.916 & 15 & 324 \\
\hline
\end{tabular}

\subsubsection{Assessment of appropriateness of data for factor analysis}

The Kaiser-Meyer-Olkin (KMO) and Barlett's test can be used to determine whether the data obtained from the study group is consistent with the explanatory factor analysis (ECA) (Büyüköztürk, 2010; Çokluk, Şekercioğlu \& Büyüköztürk, 2012; Karagöz \& Kösterelioğlu, 2008). As a result of the KMO test, it is interpreted that factor analysis cannot be continued if the KMO value is lower than 0.5 (Çokluk et al., 2012). The KMO value for this study was 0.9 that is quite adequate for research sample. Showing the suitability of the data for factor analysis, the Bartlett's test result was also significant $\left(\chi^{2}=2668.006, p=0.000\right)$ (See Table 6). 
Table 6: KMO and Bartlett's test results

\begin{tabular}{|c|c|c|}
\hline KMO Test & & 0.936 \\
\hline \multirow{3}{*}{ Bartlett's Test } & $\begin{array}{l}\text { Chi- } \\
\text { square }\end{array}$ & 2668.006 \\
\hline & df & 105 \\
\hline & p. & 0.000 \\
\hline
\end{tabular}

\subsubsection{Construct validity}

For evaluating construct validity, the results of both EFA and CFA were presented for the items of the EWPL-TR. Based on the findings, the principal component method and varimax rotation were applied as EFA of the 15-item of the EWPL-TR. As shown in the following table, the 15-item EWPL-TR appears to be a two-factor structure and accounts for $60.0 \%$ of the total two-factor variance. The first factor identified $31.6 \%$ of the total variance and the second factor identified $28.4 \%$ of total variance. A two-factor structure emerged that explains $60.0 \%$ of the total variance resulting from factor analysis with an eigenvalue greater than 1 (See Table 7).

Table 7: Total variance explained

\begin{tabular}{|c|c|c|c|c|c|c|c|c|c|}
\hline \multirow{2}{*}{ 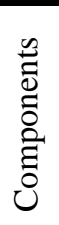 } & \multicolumn{3}{|c|}{ Initial eigenvalues } & \multicolumn{3}{|c|}{ Extraction sums of squared loadings } & \multirow{2}{*}{$\begin{array}{l}\text { Rotation } \\
\text { loadings } \\
\text { Total }\end{array}$} & \multirow{2}{*}{$\begin{array}{c}\text { sums } \\
\text { \% Of } \\
\text { the } \\
\text { Variance }\end{array}$} & \multirow{2}{*}{$\begin{array}{c}\text { of squared } \\
\begin{array}{c}\text { Cumulative } \\
\%\end{array}\end{array}$} \\
\hline & Total & $\begin{array}{c}\% \text { Of } \\
\text { the } \\
\text { Variance }\end{array}$ & $\begin{array}{c}\text { Cumulative } \\
\%\end{array}$ & Total & $\begin{array}{c}\% \text { Of } \\
\text { the } \\
\text { Variance }\end{array}$ & $\begin{array}{c}\text { Cumulative } \\
\%\end{array}$ & & & \\
\hline 1 & 7.194 & 47.960 & 47.960 & 7.194 & 47.960 & 47.960 & 4.733 & 31.553 & 31.553 \\
\hline 2 & 1.805 & 12.033 & 59.993 & 1.805 & 12.033 & 59.993 & 4.266 & 28.440 & 59.993 \\
\hline 3 & 0.850 & 5.667 & 65.660 & & & & & & \\
\hline 4 & 0.645 & 4.300 & 69.960 & & & & & & \\
\hline 5 & 0.631 & 4.209 & 74.168 & & & & & & \\
\hline 6 & 0.561 & 3.737 & 77.905 & & & & & & \\
\hline 7 & 0.547 & 3.646 & 81.551 & & & & & & \\
\hline 8 & 0.517 & 3.446 & 84.997 & & & & & & \\
\hline 9 & 0.405 & 2.698 & 87.696 & & & & & & \\
\hline 10 & 0.389 & 2.591 & 90.287 & & & & & & \\
\hline 11 & 0.356 & 2.372 & 92.659 & & & & & & \\
\hline 12 & 0.328 & 2.187 & 94.846 & & & & & & \\
\hline 13 & 0.283 & 1.886 & 96.732 & & & & & & \\
\hline 14 & 0,249 & 1.661 & 98.393 & & & & & & \\
\hline 16 & 0,241 & 1.607 & 100.000 & & & & & & \\
\hline
\end{tabular}

When the scree plot test graph is examined (See Figure 4), it is seen that limiting the factor number to two is sufficient. When the distribution of the items according to the factors after the varimax rotation method is examined, it is seen that all the materials provide logical integrity in terms of the factor structures. 


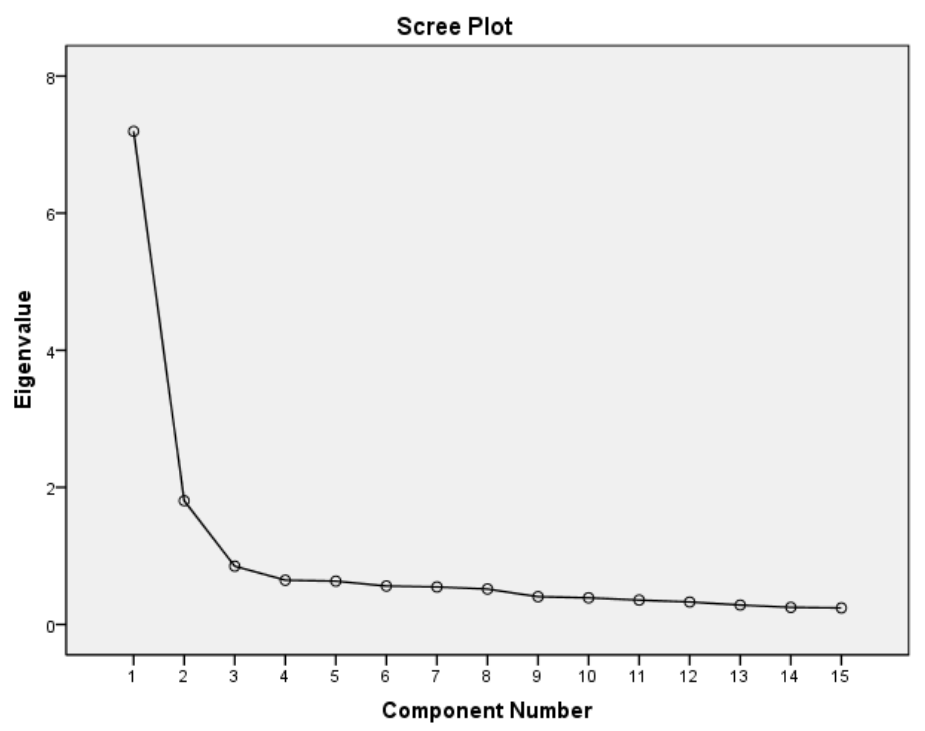

Figure 4: Scree Plot Test Graph

According to the factor loadings which are shown in the following table (See Table 8), since the distances between the loads of the factors in which the items are collected must be at least $10 \%$ of the distance between them, there is no item which does not comply with this rule. As a general rule, regardless of the sign value, the load value higher than 0.60 is high, and the load value between 0.30 and 0.59 can be defined as moderate values (Büyüköztürk, 2002).

Table 8: Varimax-rotated two-factor solution for the EWPL-TR

\begin{tabular}{lll} 
ITEMS & Factor 1 & Factor 2 \\
\cline { 2 - 3 } Item1 & 0.538 & \\
\hline Item6 & 0.582 & \\
\hline Item4 & 0.658 & \\
\hline Item13 & 0.711 & \\
\hline Item7 & 0.714 & \\
\hline Item14 & 0.720 & 0.726 \\
\hline Item10 & 0.756 & 0.783 \\
\hline Item12 & 0.790 & 0.652 \\
\hline Item11 & 0.804 & 0.782 \\
\hline Item2 & & 0.816 \\
\hline Item3 & & 0.668 \\
\hline Item5 & &
\end{tabular}


When the items belonging to the factors are examined; nine expressions were collected under the first factor, and these expressions and load values and other statistical values are shown in the following table (See Table 9). This factor can be named as "Positive EWPL-TR factor". The factor loads of the positive EWPL-TR factor were determined to be between 0.53 and 0.80 . The positive EWPL-TR factor has a high reliability, which is 0.91 .

Table 9: Positive EWPL-TR factor

\begin{tabular}{lcc}
\hline \multicolumn{1}{c}{$\begin{array}{c}\text { Factor 1: Positive EWPL-TR } \\
\text { Factor }\end{array}$} & Factor Load & Factor Reliability \\
\hline Item1 & 0.538 & \\
\hline Item6 & 0.582 & \\
\hline Item4 & 0.658 & \\
\hline Item13 & 0.711 & \multirow{2}{*}{0.905} \\
\hline Item7 & 0.714 & \\
\hline Item14 & 0.720 & \\
\hline Item10 & 0.756 & \\
\hline Item12 & 0.790 \\
\hline Item11 & 0.804 &
\end{tabular}

Six expressions were collected under the second factor, and these expressions, load values and other statistical values are shown in the following table (See Table 10). This factor can be named as "Negative EWPL-TR factor". The factor loads of the negative EWPL-TR factor were determined to be between 0.65 and 0.82 . The negative EWPL-TR factor has a high reliability, which is 0.86 .

Table 10: Negative EWPL-TR factor

\begin{tabular}{|c|c|c|}
\hline $\begin{array}{c}\text { Factor 2: Negative EWPL-TR } \\
\text { Factor }\end{array}$ & Factor Load & Factor Reliability \\
\hline Item15 & 0.668 & \multirow{6}{*}{0.864} \\
\hline Item5 & 0.652 & \\
\hline Item2 & 0.726 & \\
\hline Item3 & 0.783 & \\
\hline Item8 & 0.782 & \\
\hline Item9 & 0.816 & \\
\hline
\end{tabular}

\subsubsection{CFA results}

The accuracy of the two-dimensional factorial structure based on the results of EFA was tested by CFA. Since there is no single statistical significance test used to assess the fitness of the model generated using the obtained data, the fact that many measurements are considered simultaneously in the process of evaluating the model in the study has been taken into consideration. In the CFA, different indices were used to assess the fitness of a model, and the most commonly used ones are; the root mean square error of approximation (RMSEA) and comparative fit index (CFI) (Tabachnick \& Fidell, 2007). In this study, the values of chi-square $(\chi 2)$, RMSEA, CFI, goodness of fit index, adjusted good fit index (AGFI) and normed fit index (NFI) were evaluated on the basis of.

When performing the CFA analysis of EWPL-TR, the subscales of the scale were called as positive dimension and negative dimension. Necessary modifications have been carried out and the EWPL-TR scale has been modified from EM11 to EM7 and from EM14 to EM13 (See 
Figure 5). As shown in the following figure, EM10 is the most important item with coefficient of 0.86 in the positive dimension whereas EM8 is the most important item with a coefficient of 0.82 in the negative dimension. In addition, the relationship between positive and negative dimension is 0.7 , and the relationship between them is significant ( $\mathrm{p}=0.000)$. The results of the CFA analysis in which the subscales of the EWPL-TR are included are given in the following table (See Table 11).

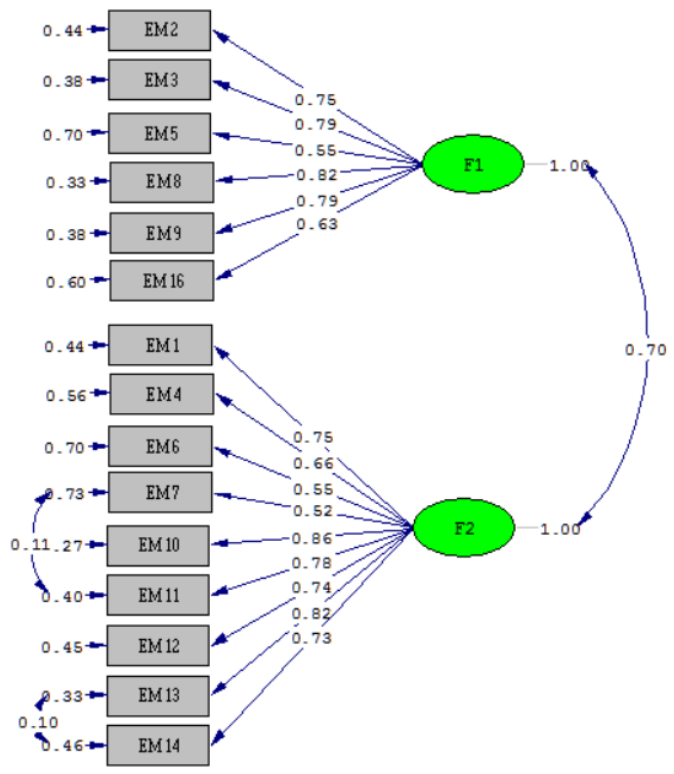

Chi-Square $=217.17, \mathrm{df}=87, \mathrm{P}-\mathrm{value}=0.00000, \mathrm{RMSEA}=0.068$

Figure 5: CFA Results for EWPL-TR

Table 11: EWPL-TR model results

\begin{tabular}{lccc}
\hline Factor/Item & Standardized Loads & $\mathrm{t}$-value & $\mathrm{R}^{2}$ \\
\hline Positive Dimension & & & \\
\hline EM1 & 0.75 & 15.42 & 0.56 \\
\hline EM4 & 0.66 & 13.04 & 0.44 \\
\hline EM6 & 0.55 & 10.36 & 0.30 \\
\hline EM7 & 0.52 & 9.61 & 0.27 \\
\hline EM10 & 0.73 & 18.77 & 0.73 \\
\hline EM11 & 0.78 & 16.17 & 0.60 \\
\hline EM12 & 0.74 & 15.10 & 0.55 \\
\hline EM13 & 0.82 & 17.59 & 0.67 \\
\hline EM14 & 0.73 & 14.83 & 0.054 \\
\hline Negative Dimension & & & \\
\hline EM2 & 0.75 & 15.12 & 0.57 \\
\hline EM3 & 0.79 & 16.35 & 0.62 \\
\hline EM5 & 0.55 & 10.23 & 0.51 \\
\hline
\end{tabular}




\begin{tabular}{llll}
\hline EM8 & 0.82 & 17.28 & 0.67 \\
\hline EM9 & 0.79 & 16.35 & 0.62 \\
\hline EM16 & 0.63 & 12.11 & 0.40 \\
\hline
\end{tabular}

It is possible to say that the compliance criteria for the CFA analysis of EWPL-TR are among the acceptable limits. Other than these criteria, $\chi^{2}(87)=217.17 ; \chi^{2} / \mathrm{dF}=2.50<3$ is another indicator used to determine model suitability and is another indicator that the model is perfectly in terms of statistics (See Table 12). The table shows that the RMSEA value of the developed scale is in acceptable limits $($ RMSEA $=0.07)$. Furthermore, the SRMR and GFI values are within the acceptable fit index $(\mathrm{SMRM}=0.05)$ and $(\mathrm{GFI}=0.9)$. Besides the AGFI value is within the fit index (AGFI $=0.9)$. As a result of the CFA analysis, the items were confirmed to have related factors at $95 \%$ confidence level $(\mathrm{p}<0.05)$ and that the compliance indices were within the acceptable compliance values and that the model consistency was within the acceptable values $(\chi 2 / \mathrm{dF}=2.50<3)$.

Table 12: Values of compliance criteria for the EWPL-TR scale CFA model.

\begin{tabular}{lccc}
$\begin{array}{l}\text { Compliace } \\
\text { Criteria }\end{array}$ & Good Fit & Acceptable Fit & $\begin{array}{l}\text { Values Of Developed } \\
\text { Scale (Current Study) }\end{array}$ \\
\hline RMSEA & $0<$ RMSEA $<0.05$ & $0.05 \leq$ RMSEA $\leq 0.10$ & 0.068 \\
\hline SRMR & $0 \leq$ SRMR $<0.05$ & $0.05 \leq$ SRMR $\leq 0.10$ & 0.054 \\
\hline GFI & $0.95 \leq$ GFI $\leq 1$ & $0.90 \leq$ GFI $\leq 0.95$ & 0.920 \\
\hline AGFI & $0.90 \leq$ AGFI $\leq 1$ & $0.85 \leq$ AGFI $\leq 0.90$ & 0.890 \\
\hline $\begin{array}{l}\text { RMSEA: Root Mean Square Error of Approximation, SRMR: } \\
\text { Square Residual, GFI: Goodness of Fit Index, AGFI: Adjusted Goodness of Fit Index } \\
\text { (Schermelleh-Engel, Moosbrugger and Müller, 2003) }\end{array}$ \\
\hline
\end{tabular}

\section{Findings}

To make an official Turkish version of the EWPL suitable for users and researchers from Turkey, the EWPL was translated into the Turkish language with permission of Professor Helen Petrie by using professional translation techniques. In this study, the use of both multiple forward and back-translation techniques prevented poor translations and enabled translations to be crosschecked. In order to translate the EWPL into Turkish, four translators who are native speakers of Turkish and advanced speakers of English were employed. With this effort, a definite translation has been performed and the EWPL-TR was structured.

Furthermore, the scale was applied to 324 undergraduate students from a Turkish University. It was evaluated for its reliability and validity, and was found to have good reliability and validity. The reliability level of the EWPL-TR scale consisting of 15 items was at a high level, which is 0.9 . The KMO value for this study was 0.9 that is quite adequate for research sample. Showing the suitability of the data for factor analysis, the Bartlett's test result was also significant $(\chi 2=2668.006, \mathrm{p}=0.000)$.

For evaluating construct validity, the results of both EFA and CFA were presented for the items of the EWPL-TR. As a result of the item analysis, the number of questions was reduced to 15 , in order to get better results. Based on the findings, the principal component method and 
varimax rotation were applied as EFA of the 15-item EWPL-TR scale. The 15-item EWPL-TR appears to be a two-factor structure and accounts for $60.0 \%$ of the total two-factor variance. The first factor identified $31.5 \%$ of the total variance and the second factor identified $28.4 \%$ of total variance. A two-factor structure emerged that explains $60.0 \%$ of the total variance resulting from factor analysis with an eigenvalue greater than 1.

When the distribution of the items according to the factors after the varimax rotation method is examined, it is seen that all the materials provide logical integrity in terms of the factor structures. When the items belonging to the factors are examined, two factors were emerged. This finding is inline with studies in literature (Seneler, 2014). The compliance criteria for the CFA analysis of the EWPL-TR are among the acceptable limits.

\section{Discussion}

It is highly critical to create and develop usable and effective systems so that studies on users' emotional behaviour as an vital angle of users' experience with systems have been getting expanding consideration in the last decade.

In this study, the EWPL (Petrie \& Harrison, 2009), which was developed to measure user emotion with systems, was adapted to Turkish. The present study has resulted in the development and validation of the EWPL-TR for usability studies in Turkey. The multi-stage translation process included the steps of initial translation, expert review, and back-translation. Psychometric evaluation of the EWPL-TR indicated an acceptable level of reliability. EWPLTR scale appears to be a two-factor structure that is inline with the literature. It is possible to say that the compliance criteria for the CFA analysis of the EWPL-TR are among the acceptable limits.

Measuring emotion which are very important for both the usability studies and psychological experiments have been very limited in Turkey. Therefore, Turkish communities have a great need for valid and reliable tools and instruments to measure users' emotion of the wide range of products and services. The results of this study showed that the EWPL-TR is a valid and reliable tool for measuring user emotion.

As a conclusion, now the EWPL is usable with Turkish users. Turkish researchers who wish to undertake research with Turkish participants related to the EWPL can use EWPL-TR. 


\section{REFERENCES}

BAHRICK, H. P., HALL, L. K., GOGGIN, J. P., BAHRICK, L. E., \& BERGER, S. A. (1994). Fifty years of language maintenance and language dominance in bilingual Hispanic immigrants. Journal of Experimental Psychology: General, 123, 264-283.

BUYUKOZTURK, S., CAKMAK, E. K., AKGUN, O. E., KARADENIZ, S., \& DEMIREL, F. (2017). Bilimsel arastirma yöntemleri. Pegem Atif Indeksi, 1-360.

BUYUKOZTURK, S. (2010). Sosyal Bilimler için Veri Analizi El Kitabi, Pegem Akademi Yayınc1lı, Ankara.

BUYUKOZTURK, S. (2002). Faktor Analizi: Temel kavramlar ve Olcek Gelistirmede Kullanımı. Kuram ve Uygulamada Egitim Yönetimi Dergisi, (32), 470-483.

COKLUK, O., SEKERCIOGLU, G. ve BUYUKOZTURK, S. (2012). Sosyal bilimler icin cok degiskenli istatistik: SPSS ve lisrel uygulamalari,Pegem Akademi Yayıncılık, Ankara.

DELGADO, P., GUERRERO, G., GOGGIN, J. P., \& ELLIS, B. B.(1999). Self-assessment of linguistic skills by bilingual Hispanics. Hispanic Journal of Behavioral Sciences, 21,3146.

GARNEFSKİ, N., \& KRAAİJ, V. (2007). The cognitive emotion regulation questionnaire: Psychometric features and prospective relationships with depression and anxiety in adults. European Journal of Psychological Assessment, 23(3), 141-149. https://doi.org/10.1027/1015-5759.23.3.141

HARNISS, M. K., EPSTEIN, M. H., RYSER, G., \& PEARSON, N. (1999). The Behavioral and Emotional Rating Scale: Convergent validity. Journal of Psychoeducational Assessment, 17(1), 4-14. Retrieved from http://proxyremote.galib.uga.edu/login?url=http://search.ebscohost.com/login.aspx?direct=true \&db= psyh\&AN=1999-13280-001\&site=ehost-live

HARRISON, C. (2009). Exploring emotional web experience: more than just usability and good design. PhD Thesis, University of York, UK.

ISEMONGER, I. \& SHEPPARD, C. (2007). A construct-related validity study on a Korean version of the perceptual learning styles preference questionnaire. Educational and Psychological Measurement, 67(2), 357-368

JORDAN, P. (1998). An introduction to Usabiliy. London: Taylor \& Francis Ltd.

KARAGOZ, Y. ve KOSTERELIOGLU, I. (2008). “İetisim becerileri degerlendirme ölceğinin faktor analizi metodu ile gelistirilmesi” Dumlupinar Universitesi Sosyal Bilimler Dergisi, 21, 81-98.

KIM, J., \& MOON, J. Y. (1998). Designing towards emotional usability in customer interfaces-trustworthiness of cyber-banking system interfaces. Interacting with Computers, 10(97), 1-29. https://doi.org/10.1016/S0953-5438(97)00037-4 
KUJALA, S., \& MIRON-SHATZ, T. (2013). Emotions, experiences and usability in real-life mobile phone use. Proceedings of CHI 2013, (November), 1061-1070. https://doi.org/10.1145/2470654.2466135

MAHLKE,S., \& MINGE,M. (2008). Affect and Emotion in Human Computer Interaction, From Theory to Applications. (C. Peter \& R. Beale, Eds.), Affect and Emotion in HCI, LNCS. https://doi.org/10.1007/978-3-540-85099-1_10

MAUSS, I. B., \& ROBINSON, M. D. (2009). Measures of emotion: A review. Cognition and Emotion, 23(2), 209-237. https://doi.org/10.1080/02699930802204677

MAXWELL, B. (1996). Translation and cultural adaptation of the survey instruments. In: Martin, M. O. \& Kelly, D. L. (eds.). Third International Mathematics and Science Study (TIMSS) Technical Report, Volume I: Design and Development. Chestnut Hill, MA: Boston College.

PALEN L., BØDKER S. (2008). Affect and Emotion in Human Computer Interaction, From Theory to Applications. (C. Peter \& R. Beale, Eds.), Affect and Emotion in HCI, LNCS. https://doi.org/10.1007/978-3-540-85099-1_10

PETER, C., \& BEALE, R. (2008). Affect and Emotion in Human Computer Interaction, From Theory to Applications. (C. Peter \& R. Beale, Eds.), Affect and Emotion in HCI, LNCS. https://doi.org/10.1007/978-3-540-85099-1_10

PETRIE, H., \& HARRISON, C. (2009). Measuring users' emotional reactions to websites. Proceedings of the 27th International Conference Extended Abstracts on Human Factors in Computing Systems CHI EA 09, 3847. https://doi.org/10.1145/1520340.1520582

PETRIE, H., \& PRECIOUS, J. (2010). Measuring user experience of websites: think aloud protocols and an emotion word prompt list. CHI'10 Extended Abstracts on Human Factors in ..., 3673-3678. https://doi.org/10.1145/1753846.1754037

SCHERMELLEH-ENGEL, K., MOOSBRUGGER, H., \& MULLER, H. (2003). Evaluating the Fit of Structural Equation Models: Tests of Significance and Descriptive Goodnessof-Fit Measures. Methods of Psychological Research Online, 8(2), 23-74. https://doi.org/10.1002/0470010940

SAURO, J., \& LEWIS, J. R. (2012). Quantifying The User Experience. Practical Statistics for user research. Morgan Kaufmann. https://doi.org/10.1007/s13398-014-0173-7.2

SENELER, C. (2014) The impact of learning styles and cultural background on users' experience of websites. PhD thesis, University of York.

TABACHNICK, B. G. ve FIDELL, L. S. (2007). Using multivariate statistics. Boston: Pearson Education Inc.

THOMPSON, B., \& LEVITOV, J. E. (1985). Using microcomputers to score and evaluate test items. Collegiate Microcomputer, 3, 163-168. 
Adnan Menderes Üniversitesi, Sosyal Bilimler Enstitüsü Dergisi, Cilt: 5, Say1: 2(Sf. 218-235)

Adnan Menderes University, Journal of Institute of Social Sciences, Vol.:5, No: 2 (pp. 218-235)

TULLIS, T., \& ALBERT, B. (2013). Measuring the User Experience: Collecting, Analyzing, and Presenting Usability Metrics: Second Edition. https://doi.org/10.1016/C2011-000016-9 


\section{Appendix}

Table A.1. Original version of the EWPL

\begin{tabular}{l|l|l|l|l|l}
\hline \multicolumn{1}{c|}{ Word List } & $1=$ Never & 2 & 3 & 4 & 5 = Very much \\
\hline Amused & & & & & \\
\hline Annoyed & & & & & \\
\hline Bored & & & & & \\
\hline Confident & & & & & \\
\hline Confused & & & & & \\
\hline Creative & & & & & \\
\hline Curious & & & & & \\
\hline Disappointed & & & & & \\
\hline Frustrated & & & & & \\
\hline Happy & & & & & \\
\hline Interested & & & & & \\
\hline Hopeful & & & & & \\
\hline Pleased & & & & & \\
\hline Relieved & & & & & \\
\hline Surprised & & & & & \\
\hline Unsure & & & & & \\
\hline
\end{tabular}

Table A.2. Finalized Turkish version of the EWPL (EWPL-TR)

\begin{tabular}{l|l|l|l|l|l}
\hline Kelime Listesi & $1=$ Hiç & 2 & 3 & 4 & $5=$ Çok \\
\hline Memnun & & & & & \\
\hline Sinirlenmiş & & & & & \\
\hline Sıkılmış & & & & & \\
\hline Kendinden Emin & & & & & \\
\hline Kafası Karışmış & & & & & \\
\hline Yaratıcı & & & & & \\
\hline Meraklı & & & & & \\
\hline Hayal Kırıklığına Uğramış & & & & & \\
\hline Usanmış & & & & & \\
\hline Mutlu & & & & & \\
\hline İlgili & & & & & \\
\hline Umutlu & & & & & \\
\hline Hoşnut & & & & & \\
\hline Rahatlamış & & & & & \\
\hline Güvensiz & & & & &
\end{tabular}

